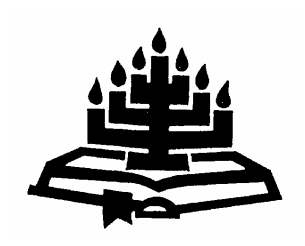

\title{
Die sosio-historiese en sosio-linguistiese aspekte van die leksikale veranderings van die 1936- en 2001-psalmomdigtings
}

\author{
S. van Helden \& A.E. Coetzee \\ Departement Afrikaans \\ Universiteit van Johannesburg \\ JOHANNESBURG \\ E-pos: mvhelden@mweb.co.za \\ E-pos: aec@rau.ac.za
}

\begin{abstract}
The socio-historical and socio-linguistic aspects of changes in the lexicon of the 1936 and 2001 rhyming of psalms

The singing of the psalms is historically associated with the accuracy of meaning transmitted by Scripture by means of userfriendly language usage. The renewing of an aging language is important for subsequent generations to facilitate meaningful interpretative singing of the psalms. By elimination of the large amount of archaic lexical expressions of the 1936 rhyme from the 2001 version, a clear movement in the reformative religious register of Afrikaans was achieved. The 2001 rhyme accelerates the process of elimination of such archaic and inaccessible words from the register. The movement of inaccessible words and the availability of Afrikaans synonyms to facilitate an effective transfer of meaning in such a new rhyme, were tested according to three social variables. Simplification is the most prominent linguistic force that manifests itself in the 2001 rhyming of the psalms. The psalmographer has used a totally new approach by using a selection of techniques in the 2001 rhyme. Observing the presence of intense change in the most conservative register of a language, that of religion, emphasises the intensity of the social and linguistic powers at work in Afrikaans.
\end{abstract}




\section{Opsomming}

Die sosio-historiese en sosio-linguistiese aspekte van die leksikale veranderings van die 1936- en 2001psalmomdigtings

Histories gesien, word psalmsang verbind met Skrifgetroue betekenisoordrag deur middel van gebruikstaal. Ter wille van nuwe geslagte is vernuwing van die verouderde taal 'n noodsaaklikheid. Die behoefte aan 'n nuwe omdigting met 'n nuwe religieuse register het die 2001-omdigting tot gevolg gehad. Met die 2001-omdigting is gepoog om die skeiding tussen die formele religieuse register en die hedendaagse gebruikstaal te oorbrug. Deur die groot aantal woorde wat in die 1936-beryming as argaïsmes voorkom uit die 2001-omdigting weg te laat, het verskuiwing in die Afrikaanse reformatoriese religieuse psalmregister plaasgevind. Die waarneming dat intense verandering in die religieuse register voorkom, beklemtoon die intensiteit van die sosiale en linguistiese kragte wat werksaam is in Afrikaans. Die uitbeweegproses van verouderde woorde is aan die hand van drie sosiale veranderlikes getoets, asook die beskikbaarheid van sinonieme in Afrikaans, om Skrifgetroue betekenisoordrag in 'n nuwe omdigting te bewerkstellig. Daar is tot die slotsom gekom dat vereenvoudiging as linguistiese krag in die 2001-omdigting sterk na vore kom en dat betekenisoordrag deur verskillende tegnieke in die 2001-omdigting verseker is.

\section{Inleiding}

Vanaf 1936 tot en met 2001 het drastiese veranderings in die SuidAfrikaanse samelewing plaasgevind. Wanneer 'n gemeenskap aan veranderings onderworpe is, is sy taal ook onderworpe aan verandering. Taalverandering word die beste in die leksikon waargeneem (Burling, 1992:86). Indien betekenis van woorde deur die geslagte só verander dat die sprekers van een geslag nie meer begryp wat die ander geslag bedoel nie, het intense taalverandering reeds plaasgevind (Dirven, 1998:220).

In hierdie bydrae word die vereistes by psalmberymings/-omdigtings kortliks uiteengesit en word aangetoon hoe die vereistes histories toegepas is. Aangesien die sosiale faktor by die gebruik van die psalms sterk na vore kom, is ook aandag gegee aan reaksies en gesindhede van psalmgebruikers teenoor die nuwe religieuse register in die 1933- en 1983-Bybelvertalings en berymings.

Hieronder word beredeneer dat die leksikale veranderingsproses in die psalmregister duidelik aantoonbaar is. Leksikale items van die 
1936-beryming is nagegaan en 'n aantal argaïsmes is geïdentifiseer. 'n Dertigtal leksikale items is deur middel van 'n vraelys aan 450 referente binne die reformatoriese religieuse groep voorgehou. Die religieuse groep, ingedeel in drie ouderdomsgroepe, is getaak om vas te stel of dié argaïsmes tans steeds 1) geken en 2) gebruik word en 3) of die huidige leksikon oor sinonieme vir die argaïsmes beskik. Die belang van sinonieme vir die argaïsmes is om aan te toon dat die woord wat in die 1936-beryming gebruik is, maar nie in die 2001omdigting voorkom nie, se betekenis nie verlore gaan nie.

Linguistiese- en sosiale faktore, asook die tempo van veranderings deur die uitfaseringsproses binne die behoudende reformatoriese religieuse register, toon dat van ander tegnieke (vgl. 11) gebruik gemaak is om betekenis-oordrag in die 2001-omdigting te bewerkstellig. Hierdie tegnieke moet veral gesien word in die lig daarvan dat die omdigter nie van sinonieme gebruik gemaak het om die woorde van die 1936-beryming te vervang nie.

Ter stawing van die uitfaseringsproses word slegs een leksikale item as voorbeeld voorgehou, naamlik snode. Aan die hand van dié leksikale item word die verandering, verdwyning of vernuwing van woorde in die 2001-omdigting verduidelik.

\section{Vereistes by psalmberymings/-omdigtings}

Die primêre vereiste vir psalmberyming word steeds gevolg soos Calvyn die vereiste vasgestel het (d'Assonville, 2000:5). Die vereiste hou in dat die beryming vanuit die Hebreeuse grondteks moet geskied ten einde 'n getroue betekenisoordrag te verseker. Dit hou verder in dat digterskap en menslike versiering aan die Woord ondergeskik moet wees, dat die beryming die sang in die erediens moet bevorder en dat die styl eenvormigheid moet vertoon.

Deur die eeue is psalms in verskillende tale op 'n verskeidenheid wyses verwoord, soos byvoorbeeld deur metriese lirieke, die volgreeks en metriese psalmversberymings (Cabaniss, 1985:194, $197,198,200,205)$. Aangesien tale verouder en verander, het 'n sekondêre vereiste by vertalings en berymings ter sprake gekom (Nienaber, 1934:10-14; Conradie, 1986:466-469, 472; GKSA, 1982:639-644; GKSA, 1994:561). Die sekondêre vereiste behels die toepassing van gebruikstaal, dus hoe die primêre vereiste gestalte kry. Gebruikstaal is derhalwe van belang, aangesien taal direk verbonde is aan die primêre vereiste. 
Skrifgetroue betekenisoordrag, daargestel deur die hedendaagse gebruikstaal, verseker die reformatoriese psalmgebruikers dat die teks as betroubaar toegeëien en gebruik kan word.

\section{Vereistes histories toegepas}

Bybelvertalings en psalmberymings gaan hand aan hand, aangesien taal by albei tekste ' $n$ veranderlike is. Tweehonderd jaar na die Reformasie is op die Sinode van Dordrecht (1618/1619) besluit om 'n nuwe en meer toeganklike Nederlandse vertaling daar te stel. Om betekenisoordrag te verseker, is so getrou moontlik gebly aan die oorspronklike tale (primêre vereiste) (Van Itterzon, 1960:442; Bos, 1960:461). Nienaber (1934:10-14) meld dat in dié vertaling verouderde woordgebruik weggelaat is en dat keuses gemaak is waar Nederlands 'n oorvloed of tekort in die woordeskat gehad het. Op 29 Julie 1637 het die State-generaal die Bybelvertaling in sewentiende-eeuse gebruikstaal goedgekeur. Op taalkundige vlak het die Statebybel in hierdie tydperk vir Nederlands as taalnormeerder gedien.

Die Statebybel en die Nederlandse psalmboek het in 1652 saam met Jan van Riebeeck na Suid-Afrika gekom. Teen 1909 het die taal weereens sodanig ontwikkel dat die Nederlandse teks nie meer vir die lesers toeganklik was nie. In 1916 is die besluit deur die Bybelvertalingskommissie geneem om 'n nuwe Bybelvertaling daar te stel. Raidt (1994:325) noem dat taaladviseurs Totius bygestaan het om weg te breek van die Statebybel se styl. Volgens Nienaber (1934:122-126) is verouderde woorde weggelaat en vereenvoudiging van Hollandse vorme is toegepas. By sommige verse is verandering en invoeging toegepas, terwyl by ander verse besluit is om dieselfde volgorde van sinne te bewaar ter wille van die presiese weergawe daarin. Conradie (1986:467-469) noem dat taalnormering ook in daardie tydperk plaasgevind het, aangesien by die destydse spelreëls aangepas is en geskryf is soos gepraat is.

Die eerste Afrikaanse psalmberyming deur Totius het in 1936 gevolg. Omdat gepoog is om aan die primêre vereiste te voldoen, het Totius grootliks op die Nederlandse Stateberyming van 1773 gesteun (Kannemeyer, 1977:244; Hattingh, 2002; Vos, 2002:4).

Teen 1968 het die Bybelgenootskap opdrag gegee dat 'n nuwe Bybelvertaling uit die oorspronklike tale moes verskyn. Hierdie Bybelvertaling moes ook dien as taalnormeerder en taalbarometer (Conradie, 1986:468). Aldus Jordaan (1999:5) moes die vertalers rekening hou met taalontwikkeling volgens die beginsels van die 
vertaalwetenskap en die jongste resultate van navorsing. $\mathrm{Na}$ aanleiding hiervan is die Dinamies Ekwivalente-vertaalmetode (DE) voorgestaan en deurgevoer. Aan die hand van hierdie metode is die Bybelse idioom oorgebring na die hedendaagse idioom.

Die 2001-omdigting het eers 18 jaar ná die 1983-Bybelvertaling verskyn. Hiermee het Cloete, in samewerking met talle kommissies, gepoog om die hart van die psalms (volgens die primêre vereiste) digterlik in "nuwe, helder Afrikaans" (volgens die sekondêre vereiste) aan die klop te sit (Retief, 2001:25).

\section{Reaksies op verandering in die religieuse register}

Volgens Rautenbach $(1995: 204,205)$ is dit 'n wêreldwye verskynsel dat mense nie aan religeuse taal wil verander nie. Bolinger (1981:257-262) skryf oor die remmende invloed van religieuse groepe soos volg: "religious tradition often preserves a contact that otherwise would have faded". Die onwilligheid tot aanvaarding van 'n nuwe religieuse register beskryf Aitchison (1991:13) soos volg:

purists behave as if there was a vintage year when language achieved a measure of excellence which we should all strive to maintain. Infact, there never was such a year.

Aanvaarding van die Bybelvertaling (1933) en psalmberyming (1936) is met toejuiging én met afkeur begroet (Nienaber, 1934:17, $26,31,44,70,181)$. Positiewe en negatiewe reaksies is ook opgemerk met die Nuwe Bybelvertaling (1983) en die 2001omdigting (Bogaardts, 2002; Coetzee, 1997:5; Erasmus, 1988:5371; GKSA, 1982: 639-644; Vos, 2002:7; Jackson, 2001:3).

Volgens die primêre en sekondêre vereistes kan gesindhede tydens die aanvaardingsproses, in twee groepe ingedeel word. Eerstens word die Bybel- en psalmgebruiker, wat die primêre vereiste (betekenisoordrag) voor oë hou, as behoudend getipeer (Nienaber, 1934:21). Tweedens word dié met 'n negatiewe siening oor die sekondêre vereiste, as konserwatief getipeer. Laasgenoemde groep voeg 'n mate van sakrale onaantasbaarheid aan die voorafgaande vertaling en ag dit hoër as die ontwikkeling wat in die taal plaasvind (Nienaber, 1934:17).

\section{Leksikale verandering in die psalmregister}

Gedurende die sewe dekades sedert 1936 het die 1936-woordeskat by psalmgebruikers uitgedien geraak. Die uitgediende register het vervreemding by psalmgebruikers veroorsaak. Die gevolg was dat 'n 
nuwe omdigting met die hedendaagse gebruikstaal as register geskep is.

Die feit dat die samelewing intens komplekser geraak het, is die eerste en grootste aanvoerbare rede waarom die 1936-beryming uitgedien geraak het. Kompleksiteit van 'n samelewing word, volgens Dirven (1999:243), op taalkundige vlak die beste waargeneem deur aantoonbare veranderinge in die leksikon.

Die sosiale kompleksiteit in Suid-Afrika is die afgelope sewe dekades onder andere bewerkstellig deur die verstedelikingsproses, die apartheidstydperk, die verengelsingsproses, die regeringsbeleid insake voorkeurtaalgebruik, ' $n$ pro-Engelse gesindheidstoename by Afrikaanssprekendes, sekularisme en ook globalisering.

'n Tweede aanvoerbare rede waarom die 1936-beryming by die hedendaagse psalmsanger uitgedien geraak het, is die gebruik van die "argaïstiese woorde en segswyses en ander taalonsuiwerhede" (GKSA, 1994:561). Die religieuse register is met die 2001-omdigting nader aan die huidige standaardtaal gebring. Die register van die Nuwe Bybelvertaling (1983) het die omdigting sterk beïnvloed. Hedendaagse gebruikstaal is op dié wyse as religieuse register genormeer.

Deur die bekendheid en ooreenstemming van die religieuse register met die gebruikstaal van die hedendaagse psalmsanger, is die skeiding tussen die voorheen formele religieuse register en die huidige gebruikstaal oorbrug. Eksklusiwiteit is verminder (Van den Berg, 2000:138) en verstaanbaarheid is nagestreef (Retief, 2001:25). Verstaanbaarheid lê altyd op die vlak van betekenis, naamlik om semantiese kerngegewens te behou te midde van verandering en om effektiewe interpretasiemoontlikhede van betekenisvelde vir die psalmgebruiker daar te stel (Cloete, 1998b:509; Dorsey, 1999:37, 38; Vos, 2002:4).

\section{Empiriese steekproef}

'n Empiriese steekproef wat gefokus het op leksikale veranderinge in die 1936-psalmberyming en 2001-psalmomdigting, is onderneem. Aan die hand van 'n vraelys wat deur 450 referente ingevul is, is leksikale ontwikkeling binne die religieuse register vanaf 1936 tot 2001 vasgestel. Ander sosiale faktore soos sosiale verbintenisse, kreatiwiteit en kognitiewe vermoëns, die onvolkome leer van kinders en taalkontak lewer ook ' $n$ bydrae tot taalverandering (Burling, 1992:316-319). In hierdie steekproef is dié sosiale faktore nie in 
berekening gebring nie, aangesien slegs op leksikale ontwikkeling gefokus is.

Die respondente wat die vraelys ingevul het, was van Afrikaanse reformatoriese kerke, naamlik die Nederduitse Gereformeerde Kerk (NG), die Nederduitsch Hervormde Kerk (NH) en die Gereformeerde Kerke in Suid-Afrika (GKSA). Respondente uit dié drie kerkverbande is uit vyf streke in Gauteng genader om die vraelys in te vul, ten einde tot 'n verteenwoordigende gevolgtrekking te kon kom.

Die respondente was geslagtelik gelykop en het in drie groepe geressorteer, naamlik dooplimate (tot 19 jaar), belydende lidmate (vanaf 20-59 jaar) en senior lidmate (bokant 60 jaar). Deur die ouderdomsverspreiding is gepoog om die aktiewe en passiewe gebruik in die veranderingsproses van die woorde aan te toon.

Drie Afrikaanse reformatoriese kerke is as teikengroep geneem, aangesien dié drie kerkverbande die 1936-psalmberyming sedert 1936 gebruik het. Die NG Kerk en NH Kerk het met verloop van tyd toevoegings tot hulle liedereskat gedoen. Die 1936-beryming is derhalwe nie uitsluitlik, soos in die geval van die Gereformeerde Kerke, gebruik nie. Die 2001-omdigting is in 2002 deur die NG- en $\mathrm{NH}$-kerke as kerklied aanvaar, terwyl die GKSA eers in 2003 tot dié stap oorgegaan het. Hierdie drie kerklike instansies het die afgelope sewentig jaar dus as taalbehoudende sosiale instellings gefunksioneer.

Slegs 30 woorde uit die 1936-beryming wat as verouderde taal kon voorkom, is volgens woordsoortelike onderskeiding vir die vraelys gekies. Van elke respondent is verwag om aan te toon of die gegewe woorde vir hom/haar bekend of onbekend is, om die gebruiksfrekwensie van die gegewe woorde aan te dui en om 'n sinoniem in die plek van die ouer woord te verskaf.

Die 30 woorde op die vraelys was die volgende: onspoed, sponde, skrede, vlees, smaad, erbarme, genaak, skrei, deurskou, verswind, toef, ontsluier, snode, strenge roede, geswind, altoos, sawends, geheellik, in gedagtenis bring, van ganser harte, deur smart omgewe, ... my hart geneë, stem al week, toets my gange, van begin af is gewees, met al wat leef, is uwe Heer, God der ere, ten troon sit en ter ore neem. 


\section{Sosiale veranderlikes}

Die drie sosiale veranderlikes wat met behulp van die vraelys getoets is, is die drie reformatoriese kerkverbande, ouderdom en geslag.

\subsection{Kerkverbande as sosiale veranderlike}

Onafhanklikheid van die kerkverband of buite die kerkverband beteken dat dié betrokke woord op die vraelys nie alleen beperk is tot die religieuse register van 'n bepaalde kerkverband nie. Die woord word dus ook as gebruikstaal gebesig. Indien die woordgebruik beperk is tot die betrokke kerkverbande, funksioneer dié betrokke woord afhanklik of binne kerkverband.

\subsubsection{Bekendheid/onbekendheid van leksikale items}

Die NG Kerk toon in vergelyking met die ander twee kerkverbande die laagste frekwensie bekendheid $(49,7 \%)$ met die 30 woorde uit die 1936-beryming. Die $\mathrm{NH}$ Kerk toon $54,2 \%$ bekendheid en die GKSA toon in vergelyking met die ander twee kerkverbande, die hoogste frekwensie bekendheid, naamlik $72,3 \%$.

Vier woorde wat afhanklik van die kerkverband 'n baie lae bekendheidsfrekwensie toon, is sponde, verswind, onspoed en snode. Die gemiddelde bekendheid by al drie kerkverbande vir hierdie woorde is $26,2 \%$, terwyl uitdrukkings binne kerkverband 'n sterk neiging tot bekendheid vertoon.

'n Aantal uitdrukkings uit die 1936-beryming toon 'n hoë bekendheidsfrekwensie, naamlik $82,6 \%$. Die betrokke uitdrukkings is: in gedagtenis bring, van ganser harte, deur smart omgewe, my hart geneë om, God der ere en strenge (roede).

\subsubsection{Gebruik/onbruik van leksikale items}

Die frekwensie van gebruik toon die gebruik van die woord, al dan nie. Die volgende woorde is uit die drie kerkverbande aangewys as dié woorde wat onafhanklik van die kerkverband feitlik nooit meer gebruik word nie: sponde, snode, verswind, erbarme, genaak, ... gange, ... week, skrei, God der ere, is uwe Heer, sawends, geneë ..., ontsluier, altoos, skrede en smaad. Die gemiddelde persentasie by die verskillende kerkverbande vir dié 16 woorde is die volgende: die $\mathrm{NH}$ Kerk $74,9 \%$, die NG Kerk $80,2 \%$ en die GKSA 76,0\%. Dié woorde is vir die hedendaagse Afrikaanssprekende dus argaïes. 
Die gebruiksfrekwensie van vlees toon dat dié woord wel buite kerkverband, dus as gebruikstaal, funksioneer. Slegs $25,1 \%$ gebruik nooit die woord in gewone gebruikstaal nie. Die gebruiksfrekwensie van die oorblywende dertien woorde hang van die kerkverband af. Die onbruik van die woorde is in die NG Kerk 76,3\%, in die NH Kerk $63,2 \%$ en in die Gereformeerde Kerke 66,9\%. Die onbruik van hierdie dertien woorde is gemiddeld $68,8 \%$ by al drie kerkverbande. Die NH Kerk gebruik die woorde die meeste, terwyl die NG Kerk die woorde die minste gebruik.

Die respondente het dus sterk aanduiding gegee dat die woorde nie meer binne die reformatoriese register gebruik word nie.

\subsubsection{Korrekte sinonieme vir leksikale items}

Binne die spesifieke kerkverbande is korrekte sinonieme deur die referente aan die volgende woorde en uitdrukkings gegee: al wat leef, van ganser harte, deur smart omgewe, ter ore neem, maak my hart geneë, God der ere, is uwe Heer, is gewees, toets my gange, ten troon sit, smaad, deurskou, geheellik, stem al week, erbarme, skrede, toef, skrei, geswind, onspoed, sponde.

Die respondente uit die $\mathrm{NH}$ Kerk het $64,4 \%$ korrekte sinonieme verskaf, die NG Kerk $63,8 \%$ en die respondente van die Gereformeerde Kerke het deurgaans die hoogste frekwensie korrekte sinonieme gegee, naamlik $77,8 \%$. Die gemiddeld van al drie kerkverbande is $68,6 \%$.

Die hoogste frekwensie korrekte sinonieme (bo 77\%) is vir uitdrukkings gegee. Die uitdrukkings wat ter sake is, is van ganser harte, deur smart omgewe, maak my hart geneë, al wat leef, ter ore neem, God der ere, is uwe Heer, is gewees en toets my gange.

Respondente uit al drie kerkverbande het slegs onspoed en sponde nie genoegsaam van korrekte sinonieme voorsien nie. Onspoed is slegs deur $33,8 \%$ en sponde deur $9,9 \%$ van korrekte sinonieme voorsien.

Die meeste korrekte sinonieme manifesteer die sterkste binne die kerkverband wat die langste en mees intense met die 1936beryming omgegaan het, naamlik die Gereformeerde Kerke. Die hoë frekwensie sinonieme wat deur die referente gegee is, dui daarop dat die gebruikstaal voldoende leksikale items bevat om die verouderde woordeskat te vervang. 


\subsubsection{Samevattend}

Buite die reformatoriese religieuse register, met ander woorde in die algemene gebruikstaal, is $23,3 \%$ van die woorde op die vraelys bekend. Binne die reformatoriese religieuse register is $76,6 \%$ van die woorde en $20,0 \%$ van die uitdrukkings op die vraelys bekend. Binne die reformatoriese religieuse register is $13,3 \%$ van die woorde op die vraelys onbekend en $43,3 \%$ van die woorde word nie deur die respondente gebruik nie. Van die woorde wat binne dié register funksioneer, is $70 \%$ van korrekte sinonieme voorsien, wat beteken dat hedendaagse sinonieme wel beskikbaar is om die verouderde woorde te vervang.

\subsection{Ouderdom as sosiale veranderlike}

Ouderdom as veranderlike toon ook die veranderingsproses in die taal aan.

\subsubsection{Bekendheid/onbekendheid van leksikale items}

Negentien van die dertig woorde blyk vir $50,2 \%$ van die jeug van reformatoriese kerke bekend te wees, naamlik skrei, erbarme, genaak, toets my gange, is gewees, skrede, altoos, sawends, deurskou, uwe Heer, ontsluier, smaad, deur smart omgewe, hart geneë, God der ere, strenge, van ganser harte, in gedagtenis bring en al wat leef. Bekendheid onder volwassenes is $82,0 \%$ en onder seniors is dit $85,5 \%$.

Woorde wat by al drie ouderdomsgroepe binne die drie kerkverbande onbekend is, is sponde, verswind en toef. Onder die jeug is dié drie woorde $17,6 \%$ bekend, onder die volwassenes $29,5 \%$ en onder die seniors $37,2 \%$. Woorde wat by die jeug in al drie kerkverbande onbekend is, maar wel by volwassenes/seniors bekend is, is snode, geswind en stem al week.

\subsubsection{Gebruik/onbruik van leksikale items}

Binne die reformatoriese kerkverbande toon die jeug die hoogste persentasie onbruik van die woorde, naamlik $82,4 \%$, terwyl die seniors die laagste persentasie onbruik toon, naamlik $54,3 \%$.

Sponde toon 'n tendens van algemene onbruik by al drie ouderdomsgroepe, naamlik $94,8 \%$. Slegs twee woorde wat onafhanklik van die drie kerkverbande onder alle ouderdomme deel vorm van die gebruikstaal, is vlees en strenge. Die twee woorde se gebruiksfrekwensie is hoër as $50 \%$. 


\subsubsection{Gee van korrekte sinonieme}

Binne die drie reformatoriese kerkverbande het al die ouderdomsgroepe vir die volgende vier woorde verkeerde sinonieme verskaf: sponde $(9,9 \%)$, snode $(22,9 \%)$, genaak $(32,5 \%)$ en onspoed $(33,8 \%)$.

By al die ouderdomsgroepe binne die drie kerkverbande is daar 'n baie hoë frekwensie van korrekte sinonieme by die volgende woorde: vlees $(96,7 \%)$, strenge roede $(85,9 \%)$, in gedagtenis bring $(95,5 \%)$ en al wat leef $(97,1 \%)$. Die betekenis van die woorde is by alle ouderdomsgroepe bekend en bevestig dat die korrekte betekenis deur vervangende sinonieme in bykans die hele reformatoriese kerkgemeenskap bestaan.

Die tendens blyk te wees dat die jeug die laagste frekwensie toon by die verskaffing van korrekte sinonieme vir die volgende 19 woorde (53,8\%): geswind, skrei, toef, skrede, erbarme, stem al week, deurskou, altoos, smaad, ten troon sit, sawends, toets my gange, uwe Heer, is gewees, ontsluier, God der ere, hart geneë, smart omgewe en van ganser harte. Die frekwensie by volwassenes is $82,2 \%$ en by seniors $81,6 \%$.

\subsubsection{Samevattend}

Die jeug toon die minste en seniors die meeste bekendheid met die betrokke woorde. Die jeug toon 'n lae gebruiksfrekwensie van die woorde op die vraelys, terwyl die seniors die hoogste gebruiksfrekwensie toon en die jeug toon die laagste frekwensie by die verskaffing van korrekte sinonieme, terwyl die volwasse groep en seniorgroep soortgelyk is in die verskaffing van korrekte sinonieme.

\subsection{Geslag as sosiale veranderlike}

Geslag as veranderlike is ook aangewend om die mate van verandering in die taal te bepaal.

\subsubsection{Bekendheid/onbekendheid van leksikale items}

Geslag blyk geen betekenisvolle invloed uit te oefen op die bekendheid van woorde nie. Slegs twee woorde binne die drie kerkverbande toon persentasiegewys 'n verskil by die manlike en vroulike respondente. Die woorde is genaak en in gedagtenis bring. Bekendheid van genaak is $62,2 \%$ by die vroulike geslag en $52,2 \%$ by die manlike geslag. Bekendheid van in gedagtenis bring is $94,5 \%$ (vroulik) en $88,0 \%$ (manlik). Die verskil in persentasie by die 
verskillende geslagte is egter onbeduidend, aangesien die verskil slegs by $6,6 \%$ van die woorde voorkom.

\subsubsection{Gebruik/onbruik van leksikale items}

By die onbruik van 'n woord speel geslag as veranderlike nie 'n rol nie. Onbruik van die woorde dui 'n gemiddeld van $71,4 \%$ vir vroulike respondente aan en $72,1 \%$ vir manlike respondente.

\subsubsection{Die gee van korrekte sinonieme}

Die woorde wat deur albei geslagte nie van genoegsame korrekte sinonieme voorsien is nie, is onspoed, sponde, smaad, verswind en snode. Die gemiddelde veskaffing van sinonieme deur die vroulike geslag by dié vyf woorde, is $36,2 \%$ en $35,5 \%$ by die manlike geslag. Die ander 25 woorde is genoegsaam van sinonieme voorsien om betekenisoordrag te bewerkstellig en effektief te kommunikeer. Die woorde/uitdrukkings wat, ongeag geslag 'n baie hoë frekwensie korrekte sinonieme toon, is soos volg: vlees, strenge, in gedagtenis bring, van ganser harte, my hart geneë, smart omgewe, al wat leef en ter ore neem. Slegs by onspoed en smaad het die manlike respondente 'n hoër frekwensie korrekte sinonieme verskaf.

\subsubsection{Samevattend}

Geslag as sosiale veranderlike het geen invloed op die bekendheid en die gebruik/onbruik van die woorde uitgeoefen nie. Albei geslagte het genoegsame korrekte sinonieme verskaf.

\subsection{Die uitbewegingsaktiwiteit van leksikale items}

Die frekwensie van bekendheid, gebruik asook die verskaffing van die korrekte sinoniem, is die laagste onder die jeug. Sekere woorde funksioneer as passiewe kennis, terwyl die aktiewe gebruik en uitbreiding van bestaande woorde slegs in sekere gevalle voorkom. Die frekwensie van bekendheid en gebruik, toon 'n stygende lyn namate ouderdom toeneem.

Die frekwensie by die verskaffing van korrekte sinonieme toon ook 'n stygende lyn namate die ouderdom toeneem, alhoewel die hoogste frekwensie by die volwasse groep voorkom, met die seniors wat deurgaans 'n onbeduidende persentasie laer as die volwasse groep vertoon.

Volgens die vraelyste van die respondente begryp die jeug nie meer die betekenis van sommige woorde nie, terwyl die ouer geslag 
steeds kennis daarvan dra en dit steeds gebruik. 'n Passiewe kennis by die jeug van sekere woorde op die vraelys, toon die uitbewegingsaktiwiteit wat in die taal aanwesig is. Woorde wat in die proses van verdwyning is, is aantoonbaar, terwyl die verskaffing van sinonieme betekenisverlies as gevolg van woordverlies, kan voorkom.

\section{Leksikale veranderingsproses in die psalmregister}

In die geval van die 2001-omdigting behoort die gekose woorde ook met die verloop van tyd veroudering te toon, soos die geval was met die woorde van die 1936-beryming. Met 'n volgende omdigting behoort verouderde woorde uit die psalmregister te verdwyn, terwyl 'n nuwe leksikale item met toegevoegde, verminderde of sinonieme waarde in die plek van die verouderde vorm in gebruik te kom.

Beweging op leksikale vlak is in Afrikaans opvallend en dui op intense verandering wat die afgelope 70 jaar in Afrikaans, en meer spesifiek in die psalmregister, werksaam is. Woorde met 'n hoë gebruiksfrekwensie, asook die voorkeurwoordeskat van die omdigter, veroorsaak dat dié woorde dieper die register inbeweeg, terwyl die woorde uit die 1936-psalmregister wat 'n lae gebruiksfrekwensie toon, uit die religieuse register verdwyn. Waar beweging op leksikale vlak is, is taalverandering teenwoordig (Coetzee, 1982:286).

Dié uitbewegingsproses in die psalmregister is deur die studie waarneembaar. Die vergelyking tussen die vraelyswoord wat in die Skrifgedeelte van die nuwe Bybelvertaling (1983) voorkom, met die 1936-psalmberyming én die 2001-omdigting, toon duidelik dat die omdigter van die 2001-psalmomdigting die woorde van die nuwe Bybelvertaling (1983) bo dié van die 1936-psalmregister verkies het (vgl. 12). Deur die omdigter se keuse het die ouer woorde uit die hedendaagse psalmregister uitbeweeg. Die gekose woorde is derhalwe as deel van die hedendaagse psalmregister gevestig.

Die stand van die 30 woorde op die vraelys binne die uitbewegingsproses van Afrikaans, word hieronder geposisioneer. Die veranderingsproses toon die beweging van woorde in aktiewe en passiewe hoedanigheid, asook woorde wat uit die algemene Afrikaans uitbeweeg. 


\section{Buite algemene Afrikaans}

sponde

verswind

onspoed

snode

\section{Passiewe woordeskat Aktiewe woordeskat}

Genaak
geswind
erbarme
geheerlik
toef
stem al week
gange
ten troon sit
skrei
is gewees
deurskou
smart
omgewe
ter ore neem
God der ere
uwe
sawends

\author{
hart geneë \\ ontsluier \\ altoos \\ skrede \\ smaad
}

\author{
in gedagtenis bring \\ strenge ... \\ van ganser harte \\ al wat leef \\ vlees
}

Die uitbewegingsproses van dié woorde het in die afgelope 70 jaar remming ervaar (vgl. 4). Remming is veroorsaak deurdat dié woorde as psalmregister gefunksioneer het. Met die daarstel van die 2001omdigting is die veranderingsproses verhaas, deurdat van die woorde wat remming veroorsaak het, weggelaat is en ander woorde uit die 2001-gebruikstaal tot die hedendaagse religieuse register toegevoeg is. 


\section{Vereenvoudiging as linguistiese faktor by taalverandering}

Vereenvoudiging is 'n linguistiese faktor wat taalverandering bewerkstellig. Vereenvoudiging kan lei tot groter eenvoud/bondigheid en verstaanbaarheid, maar kan ook nadelig wees, deurdat presisie en betekenisoordrag daardeur ingeboet word (Chafe, 1970:38; De Klerk, 1978:2). Bolinger (1981:262) voeg hierby dat vereenvoudiging egter ook spasie maak vir uitbreiding.

\section{Taalveranderingsmeganismes}

Meganismes waardeur vereenvoudiging in taal bewerkstellig word, is onder andere funksiewisseling/splitsing en reduksie (De Stadler, 1989:220, 132), woordverlies/betekenisverlies (Langacker, 1973: 185), die gebruik van kort woordjies en sinne (Nienaber, 1965:243269; Bolinger, 1981:4), bondigheid en digterlike hegtheid deur die uitsif van onnodighede (Cloete, 1998b:511), verwydering van herhalings en die gebruik van duidelike konstruksies (Donaldson, 1988:137, 139).

Vereenvoudiging deur uitbreiding van betekenis kom voor wanneer 'n woord op meerduidige wyse nuwe interpretasies daarstel (De Villiers, 1975:128; Finegan, 1989:388, 389; Cloete, 1998b:511). Uitbreiding van betekenis geskied ook aan die hand van sinonieme, waardeur nuwe interpretasies soms plaasvind en betekenisverandering sodanig kan plaasvind (Geeraerts, 1989:192). By sinonieme as draers van verlengde betekenis, is betekenisbehoud van belang, aangesien vae kommunikasie tot verminderde betekenisoordrag en tot die verdringing van Skrifgetrouheid kan lei (De Villiers, 1975:128). In die leksikale veranderingsproses beskik Afrikaans egter oor talle sinonieme om betekenisoordrag in 'n nuwe psalmomdigting te bewerkstellig.

Taalekonomie as deel van vereenvoudiging is ter sprake wanneer minder woorde gebruik word om dieselfde saak te stel as wat voorheen deur 'n groter aantal woorde gesê is (Carstens, 1997:185). In die sosiolinguistiese proses van vereenvoudiging gaan verandering onverpoosd voort. Indien inligtingsverlies gepaard gegaan het met die veranderinge, sou daar onafwendbaar 'n ander strukturele verandering ingetree het om te kompenseer (Labov, 1972:223; 1994:31). Met die 2001-omdigting is ou woorde uitgelaat (vgl. 12) en nuwes wat bekend is binne die gebruiker se kultuur en wat 'n hoë gebruiksfrekwensie toon, is in die psalmregister ingebring. Woordverlies het egter nie by een van die 30 woorde tot betekenisverlies 
gelei nie, aangesien die omdigter aan die hand van 'n aantal tegnieke die kern/betekenis van die oorspronklike teks, óf op hegte en intense wyse, óf op uitbreidende en aanvullende wyse, effektief gekommunikeer het (vgl. 11).

\section{Tegnieke vir die behoud van betekenisoordrag}

Opvallende elemente wat die 2001-omdigting karakteriseer, is die teenwoordigheid van die kerngegewe en die betekenis/bedoeling van die grondtaal, asook die patroonmatigheid van die psalms (Cloete, 1998a:246, 247; 1998b:511; Vos, 2002:6). Die omdigter het verder ook gebruik gemaak van tegnieke om op verstaanbare en ekonomiese wyse betekenisoordrag daar te stel. Dit is deurgevoer deur binne die voorskrifte van die Bybelteks en melodie, op leksikale gebied in te kort of aan te vul (Cloete, 1998a:246, 247, 249).

Die tegnieke is deur Van Helden $(2004: 111,112)$ self benoem na aanleiding van 'n assosiasie wat gemaak is op grond van die manier waarop die woorde in die nuwe omdigting aangewend is. Die tegnieke wat in die omdigting voorkom, word hieronder genoem.

- Sigsagtegniek: in die Bybelteks van Die Bybel (Nuwe Vertaling, 1983) waar die getoetste woorde sou voorkom, val die klem op die kern van die teks. Die kern is op leksikaal kompakte wyse uitgebrei, sonder dat verskraalde segging tussen die twee punte of pole plaasvind (Venter, 1996:121).

- Konsertinametode: in die Bybelteks van Die Bybel (Nuwe Vertaling, 1983) waar die getoetste woorde sou voorkom, word die kern van die teks kompak opeengestapel, deur aanvullende, uitbreidende of ontsluitende gegewens (Cloete, 1996:19).

- Sosatiemetode: in die Bybelteks van Die Bybel (Nuwe Vertaling, 1983) waar die getoetste woorde sou voorkom, word die kerngegewens bondig opeengestapel sonder aanvullende, uitbreidende of ontsluitende gegewens (Cloete, 1996:19).

- Gloeilamptegniek: in die Bybelteks van Die Bybel (Nuwe Vertaling, 1983) waar die getoetste woorde sou voorkom, word van 'n uitdrukking gebruik gemaak wat betekenisoordrag intensiveer. Die intensiverende uitdrukking vergemaklik interpretasie wat tot maklike en relevante toepasbaarheid van die kerngegewens lei (Finegan, 1989:3; Cloete, 1998b:511).

- Snoei-en-bottegniek: in die Bybelteks van Die Bybel (Nuwe Vertaling, 1983) waar die getoetste woorde sou voorkom, vind 
drastiese vereenvoudiging van taalgegewens plaas, terwyl intensiverende betekenisoordrag en uitbreidende toepasbaarheid terselfdertyd deur middel van vereenvoudiging geskied (De Villiers, 1975:128).

\section{Leksikale verandering by snode}

Slegs die woord snode, wat deel vorm van die vraelys, word as voorbeeld gebruik om verandering aan te toon. Die vermelding van snode in 'n aantal woordeboeke vanaf 1956 tot 2000 volg hieronder:

- Verklarend Handwoordenboek der Nederlandse Taal

snood dui op boosaardig, misdadig, schandelijk (Koenen \& Endepols, 1956:984).

- Handwoordeboek van die Afrikaanse Taal

snodelik: sleg. Slecht: is 'n meer eenvoudige sinoniem met 'n meer uitgebreide betekenis, naamlik onaanzienlijk, niet goed, niet deugdelijk, verkeerd werkend, boos, boosaardig, met misdadige aanleg, moeilijk (Odendal, et al., 1984:1020).

- Verklarende Afrikaanse Woordeboek

snodelik: sleg, misdadig, deurtrap, skaamteloos (Labuschagne \& Eksteen, 1993:813).

- Verklarende Handwoordeboek van die Afrikaanse taal

snode is nie aangedui nie; wel

snodelik (deftig) sleg, misdadig, deurtrap (Odendal et al., 1994:967).

- Verklarende Handwoordeboek van die Afrikaanse Taal

snode is nie aangedui nie; wel

snodelik: (weinig gebruiklik en deftig) sleg, misdadig, deurtrap (Odendal \& Gouws, 2000:1032).

Dié woordeboeke toon duidelik dat 'n aantal sinonieme vir die gebruik van snode beskikbaar is. Deur middel van die vraelys is die sinoniem sleg vir snode verskaf, terwyl die respondente die geleentheid gekry het om self verdere sinonieme vir snode te verskaf. Die persentasie respondente wat sleg as sinoniem vir snode aangedui het, is $21,9 \%$ Die volgende korrekte alternatiewe sinoniem vir snode is deur slegs drie respondente gegee, naamlik 
misdadig. Slegs $22,9 \%$ van die respondente het korrekte sinonieme verskaf.

Die woord snode is vir $67,6 \%$ van die respondente nie bekend nie, terwyl $92,2 \%$ van die respondente die woord nooit gebruik nie. Snode maak nie deel uit van die passiewe kennis van die respondente nie. Die lae persentasie korrekte sinonieme wat verskaf is, toon dat die betekenis van snode uit die gebruikstaal verdwyn het. Sedert die 1994-HAT word snode as deftig aangegee, wat daarop dui dat snode deur dié gestandaardiseerde bron as argaïsme gereken word.

Die volgende Bybelvertalings en psalmberymings toon die gebruik van snode in Psalm 5, al dan nie.

- State Psalmberyming:

Hij, die zijn hand met bloed bevlekt,

en gruw'len met bedrog bedekt,

Tergt, als de snoodste wetverbreker,

den hoogsten Wreker (Bijbel, 1618; 1619).

- 1936-beryming:

Hy wat sy hand met bloed bevlek

en gruwels met bedrog bedek,

hy terg, as snode wetverbreker, die hoogste Wreker (Du Toit, 1987).

- Die Bybel (1971):

$U$ haat al die werkers van ongeregtigheid, $U$ sal die leuensprekers laat omkom; van die man van bloed en bedrog het die HERE 'n afsku.

- Die Bybel (Nuwe Bybelvertaling, 1983):

$U$ haat almal wat onreg doen, $U$ roei alle leuenaars uit. Die Here verafsku moordenaars en bedrieërs.

- 2000 - gewysigde Psalmberyming:

hy terg, as bose wetverbreker,

die hoogste Wreker (Buys, 2002).

- 2001-omdigting:

$U$ duld geen onreg en geen kwaad nie;

wie trots is, sal verneder word,

$U$ sal hom in die afgrond stort.

In moordenaars het $U$ 'n afsku

en leuenaars straf $U$ (Carstens et al., 2001). 
Die woord snode is in die 1936-beryming gebruik, maar nie in die betrokke teksgedeelte van die 2001-omdigting nie. In die 1936beryming van Psalm 5:5 word twee booshede in die vyfde vers genoem, naamlik hande wat met bloed bevlek is en bedrog. In die 2001-omdigting manifesteer die deel-geheel-verhouding deur bondige opstapeling en benoeming, deurdat vier booshede genoem word. Die vier booshede is: onreg, trots, moord(enaar)s en leuen(aar)s (vgl. Van Helden, 2004:137, 138). Die betekenis van die vier booshede impliseer die slegte (snode).

Samehangend hiermee word vier reaksies van God teenoor die slegte dade opeengestapel, naamlik duld nie kwaad nie, stort in afgrond, afsku en straf. Die struktuur van die omdigting beweeg tussen twee punte, naamlik God/U (punt 1) en die booshede (punt 2). Deur die hegsluitende, bondige, dog teenstellende uitbreidende opeenstapeling, word die kerngegewens duidelik gestel en interpretasiemoontlikhede uitgebrei. Geen woord-vir-woordomdigting het plaasgevind nie. Die sigsagtegniek, asook die konsertinategniek is hier toegepas (vgl. 11).

\section{Ten slotte}

Die 2001-omdigting is nie 'n woord-vir-woordvervanging van die 1936-beryming nie. Met hierdie omdigting slaag die omdigter in die "wegkom van Totius" (Retief, 2001:25). Vereenvoudiging van die 2001-omdigting is ook sigbaar, deurdat daar minder strofes in die psalms is as in die 1936-beryming. Die woorde van die 1936beryming wat deur die respondente van baie sinonieme voorsien is, maar bykans nooit deur die omdigter in die 2001-omdigting gebruik is nie, toon dat die betekenisvelde van dié woorde verbreed het. Die omdigter het van patroonmatige tegnieke gebruik gemaak om op woord-ekonomiese wyse geslaagde betekenisoordrag daar te stel. Die 2001-omdigting toon suksesvolle betekenisoordrag, ten spyte van die weglating/verlies van woorde, waaronder die betrokke 30 woorde uit die 1936-beryming. Taalverandering aan die hand van vereenvoudiging te midde van uitbreiding is teenwoordig in die nuwe Afrikaanse religieuse register. In die geval waar uitbreiding van betekenis plaasgevind het, het effektiewe kommunikasie ook plaasgevind. Die leksikale veranderings binne die reformatoriese psalmregister toon dat taalverandering in Afrikaans intens en aktief werksaam is. 


\section{Geraadpleegde bronne}

AITCHISON, J. 1991. Language change: progress or decay? Cambridge: University Press.

BIJBEL. 1618 \& 1619. Bijbel dat is de gansche Heilige Schrift bevattende al de canonieke boeken des Ouden en Nieuwen Testaments op last van de Hoog-Mog. Heeren Staten-Generaal der Vereenigde Nederlanden en volgens het besluit van de Nationale synode gehouden te Dordrecht in die jaren MDCXVIII en MDCXIX uit de oorspronklijke talen in onze Nederlandsche getrouwelijk overgezet. Leeuwarden: Jongbloed.

BOGAARDS, A.H. 2002. Toets die nuwe beryming aan die Woord alleen. http://home.spg.co.za/bogaards/sstoetsh.htm Datum van gebruik: 5 Okt. 2002.

BOLINGER, D. \& SEARS, D.A. 1981. Aspects of language. New York: Harcourt Brace Jovanovich.

BOS, F.L. 1960. Piscator. (In Grosheide, F.W. \& Van Itterzon, G.P., reds. Christelijke encyclopedie, III. Kampen: Kok. p. 461.)

BURLING, R. 1992. Patterns of language - structure, variation, change. San Diago: Academic Press.

BUYS, P.W. 2002. Gewysigde/hersiene Totius-teks van die Psalms. Aanvullende agenda vir Sinode 2000. Potchefstroom: Die GKSA deputate liturgiese sake.

BYBEL. 1971. Kaapstad: Bybelgenootskap van Suid-Afrika.

BYBEL. 1983. (Nuwe Vertaling). Eerste uitgawe. Kaapstad: Nasionale Boekdrukkery.

CABANISS, A. 1985. The background of metrical psalmody. Calvin Theological Journal, 20(1): 191-206.

CARSTENS, J.C., LOUWRENS STRYDOM, W.L., \& TROSKIE, A.J.J., reds. 2001. Liedboek van die kerk vir gebruik by die erediens en ander byeenkomste. Goodwood: NG Kerk-Uitgewers.

CHAFE, W.L. 1970. Meaning and the structure of language. Chicago: University of Chicago Press.

CLOETE, T.T. 1998a. Die omdigting van die Psalms in Afrikaans. Tydskrif vir Geesteswetenskappe, 38(4): 243-252.

CLOETE, T.T. 1998b. Prof. W.S. Prinsloo en die omdigting van die Psalms. Skrif en Kerk, 19(3): 500-512.

COETZEE, A.E. 1982. 'n Heroriëntering van die begrip standaardtaal en 'n voorstudie van die ontwikkeling van standaard-Afrikaans gedurende die 20e eeu. Tydskrif vir Geesteswetenskappe, 22(4): 271-289.

COETZEE, J.P. 1997. Rol van Bybelgenootskap ten aansien van Bybelvertaling. Die Kerkpad, 3(4):5.

CONRADIE, C.J. 1986. Die normering van Afrikaanse Bybeltaal. (In Botha, R.P. \& Sinclair, M., reds. Norme vir taalgebruik. Universiteit van Stellenbosch: Departement vir Algemene Taalwetenskap. Spil Plus, 10:464-487.

D 'ASSONVILLE, V. 2000. Totius se vereistes vir Psalmberyming. Die Kerkpad, 4(3):5.

DE KLERK, W.J. 1978. Inleiding tot die semantiek. Pretoria: Butterworth.

DE STADLER, L.G. 1989. Afrikaanse semantiek. Johannesburg: Southern Boekuitgewers.

DE VILLIERS, M. 1975. Die semantiek van Afrikaans. Pretoria: HAUM. 
DIRVEN, R. \& VERSPOOR, M., eds. 1998. Cognitive exploration of language and linguistics. Amsterdam: John Benjamins. Vertaling: Dirven, R. \& Verspoor, M., reds. 1999. Cognitieve inleiding tot taal en taalwetenschap. Amersfoort: Leuven.

DONALDSON, B.C. 1988. The influence of English on Afrikaans: a case study of linguistic change in a language contact situation. Pretoria: Seva.

DORSEY, D.A. 1999. The literary structure of the Old Testament: a commentary on Genesis - Malachi. Grand Rapids: Baker Books.

DU TOIT, J.D. 1987. Die berymde psalms in gebruik by die drie Afrikaanse kerke, t.w. Die Nederduitse Gereformeerde Kerk, Die Gereformeerde Kerk in Suid-Afrika, Die Nederduitsch Hervormde Kerk van Afrika, en Skrifberymings in gebruik by die Gereformeerde Kerk in Suid-Afrika. Tweede hersiene uitgawe. Kaapstad: Nasionale Boekdrukkery.

ERASMUS, J.C. 1988. Bewaar my Woord: kritiek op die nuwe Afrikaanse vertaling van die Bybel. Pretoria: Die skrywer. (Posbus 13816 Sinoville 0129.)

FINEGAN, E. \& BESNIER, N. 1989. Language its use and structure. San Diego: Harcourt Brace Jovanovich.

GEERAERTS, D. 1989. Wat er in een woord zit: facetten van de lexicale semantiek. Leuven: Peeters.

GEREFORMEERDE KERKE IN SUID-AFRIKA. 1982. Handelinge van die eenen-veertigste sinode te Potchefstroom op 6 Januarie 1982 en volgende dae. Potchefstroom: Herald.

GEREFORMEERDE KERKE IN SUID-AFRIKA. 1994. Handeling van die 45ste nasionale sinode te Potchefstroom op 3 Januarie 1994 en volgende dae. Potchefstroom: Herald.

\section{GKSA}

kyk GEREFORMEERDE KERKE IN SUID-AFRIKA

HATTINGH, M. 2002. Cloete vereer vir omdigting van psalms. Burger: 4, $28 \mathrm{Feb}$.

JACKSON, N. 2001. Nuwe liedboek van kerk “'n Blitsverkoper". Beeld: 3, 29 Okt.

JORDAAN, G.J.C. 1999. Redaksioneel: bywoning van kongres oor Bybelvertaling. Die Kerkblad: 5, 10 Maart.

KANNEMEYER, J.C. 1977. Totius as digter. (In Scholtz, M. Die lewende Totius - 'n bundel opstelle saamgestel vir die Totius-eeufees in 1977. Kaapstad: Tafelberg. p. 34-50.)

KOENEN, M.J. \& ENDEPOLS, J. 1956. Verklarend Handwoordenboek der Nederlandse Taal. Vierentwintigste druk. Groningen: Wolters.

LABOV, W. 1972. Sociolinguistic patterns. Philadelphia: University of Pennsylvania Press.

LABOV, W. 1994. Principles of linguistic change: internal factors. Oxford: Blackwell.

LABUSCHAGNE, F.J. \& EKSTEEN, L.C. 1993. Verklarende Afrikaanse Woordeboek. Agtste hersiene en uitgebreide uitgawe. Pretoria: Van Schaik.

LANGACKER, R.W. 1973. Language and its structure, some fundamental linguistic concepts. New York: Harcourt, Brace, Jovanovich.

NIENABER, P.J. 1934. Die geskiedenis van die Afrikaanse Bybelvertaling en 'n hoofstuk oor die vertaling van die Psalm- en Gesangboek en die Formuliere. Kaapstad: Nasionale Pers. 
NIENABER, P.J. 1965. Bybelvertaling. (In Nienaber, P.J. Taalkundige opstelle. Kaapstad: Balkema. p. 243-269.)

ODENDAL, F.F. \& GOUWS, R.H., reds. 2000. HAT: Verklarende Handwoordeboek van die Afrikaanse Taal. Kaapstad: Perskor.

ODENDAL, F.F., SCHOONEES, P.C., SWANEPOEL, C.J., DU TOIT, S.J. \& BOOYSEN, C.M. 1984. HAT: Verklarende Handwoordeboek van die Afrikaanse Taal. Johannesburg: Perskor.

ODENDAL, F.F., SCHOONEES, P.C., SWANEPOEL, C.J., DU TOIT, S.J. \& BOOYSEN, C.M. 1994. HAT: Verklarende handwoordeboek van die Afrikaanse Taal. Doornfontein: Perskor.

RAIDT, E.H. 1994. Historiese taalkunde studies oor die geskiedenis van Afrikaans. Johannesburg: Witwatersrand University Press.

RAUTENBACH, W.P. 1995. Die belangrike rol wat Nederlands gespreel het ten opsigte van die Afrikaanse Bybelvertaling. (In Ester, $\mathrm{H}$. \& Van Leuvensteijn, A. Afrikaans in een veranderende context: taalkundige en letterkundige aspecten. Amsterdam: S.A. Instituut. p. 189-205.)

RETIEF, H. 2001. 'n Nuwe lied. Rapport: 25, 4 Nov.

TAALKOMMISSIE VAN DIE SUID-AFRIKAANSE WETENSKAP EN KUNS. 1991. AWS: Afrikaanse woordelys en spelreëls. Kaapstad: Tafelberg.

VAN DEN BERG, M. 2000. Die konsep Standaardafrikaans: 'n kritiese oorsig en 'n Hallidayaanse perspektief. Potchefstroom: PU vir CHO. (Doktorale proefskrif - ongepubliseerd.)

VAN HELDEN, S. 2004. Sosiohistoriese en sosiolinguistiese aspekte van die leksikale veranderinge van die 1936- en 2001-psalmomdigtings. Johannesburg: RAU. (Ongepubliseerde M.A.-verhandeling.)

VAN ITTERZON, G.P. 1960. Helmichius. (In Grosheide, F.W. \& Van Itterzon, G.P., reds. Christelijke encyclopedie, III. Kampen: Kok. p. 422.)

VENTER, M. 1996. T.T. Cloete en die omdigting van die psalms. In die Skriflig 30(1):115-123.

VOS, C.J.A. 2002. Met 'n lied in die hart. Liedboek van die kerk: nuusberigte, artikels, persvrystellings. http://www.liedboek.co.za/persvrystellings2.htm Datum van gebruik: 5 Oktober 2002.

\section{Kernbegrippe:}

betekenis-oordrag

omdigting

psalmberymings

religieuse register

taalverandering

\section{Key concepts:}

accuracy of meaning

change in language

religious register

rhyme of the psalms

transmission 